\title{
Sick building syndrome
}

\author{
Tjandra Yoga Aditama, Sita Laksmi Andarini
}

\begin{abstract}
Abstrak
Sindroma gedung sakit adalah suatu keadaan yang menunjukkan timbulnya berbagai keluhan tidak spesifik pada sebagian besar pengguna suatu gedung. Mekanisme patofisiologinya belumlah diketahui dengan pasti. Yang jelas, terjadinya sindroma gedung sakit merupakan resultante multi faktor, dapat berupa fisik, kimiawi, biologikal dan mungkin juga faktor psikologikal. Pada sebagian besar kasus sindroma ini terjadi akibat tidak terpeliharanya sistem pemanasan, ventilasi dan pendinginan ruangan. Gejala yang timbul dapat cukup berat dan meliputi iritasi membran mukus, gejala neurotoksik, gejala menyerupai asma, keluhan di kulit, keluhan gastrointestinal dan lain-lain. Untuk menegakkan diagnosis maka beberapa prosedur perlu dilakukan, dan pemeriksaan langsung terhadap lingkungan gedung di lapangan akan amat membantu ditegakkannya diagnosis. Pencegahan terjadinya keadaan ini jauh lebih menguntungkan ketimbang mengobati keadaan yang sudah terjadi. Polusi udara dalam ruangan dan sindroma gedung sakit merupakan salah satu paradigma baru dalam ilmu kesehatan kerja dan lingkungan. (Med J Indones 2002; 11: 124-31)
\end{abstract}

\begin{abstract}
Sick building syndrome describes a number of mostly unspesific complaints of some occupants of the building. The exact pathophysiological mechanism remains elusive. It is a multi factorial event which may include physical, chemical, biological as well as psychological factors. In many cases it is due to insufficient maintenance of the HVAC (heating, ventilation, air conditioning) system in the building. Sign and symptoms can be uncomfortable and even disabling, which may include mucus membrane irritation, neurotoxic symptoms, asthma like symptoms, skin complaints, gastrointestinal symptoms and other related symptoms. There are various investigation methods to diagnose sick building syndrome, and on site assessment of the building is extremely useful. Prevention through a proactive air quality monitoring program is far more désirable than dealing with an actual sick building. Indoor air and the sick building syndrome serves as a paradigm of modern occupational and environmental medicine. (Med J Indones 2002; 11: 124-31)
\end{abstract}

Keywords: indoor air pollution, sick building syndrome, building related illness

Indoor air quality has deteriorated so much since the 1970s oil shortage and subsequent energy-efficient construction of buildings that people are becoming seriously ill by just breathing the indoor air. This is a problem with all industrial buildings. ${ }^{1}$ In the past two decades, a group of health problems related to the indoor environment--generally termed sick building syndrome (SBS)--has emerged.

In the past 20 years we have seen the replacement of naturally ventilated buildings by buildings with tight shells that are wholly or substantially dependent on mechanical ventilation. Heating, ventilation, and airconditioning (HVAC) system design, structural design, and material finishes are specified to a large extent by

Pulmonology Department Faculty of Medicine University of Indonesia / Persahabatan Hospital. Jakarta, Indonesia architects, mechanical engineers, and interior designers to meet building codes and, at the same time, provide aesthetic appeal along with structural integrity. Unfortunately, building requirements necessary to promote the health of occupants of buildings have historically been neglected or given minimal attention. This switch to tighter buildings combined with a lack of knowledge of and attention to the potential adverse health effects of ineffective ventilation and indoor air contaminants has spawned a marked increase in the number of reports of human illnesses linked to the indoor environment. ${ }^{2}$

Some contaminants causing ill health have been identified within buildings for decades (e.g., paint containing lead and allergenic components of mold spores). Indoor environmental contaminants cause building related illness (BRD) through four major mechanisms: (1) immunologic, (2) infectious, (3) toxic, and (4) irritant. Because the agents causing BRI 
routinely coexist, it is not unusual to have two or more mechanisms of disease operating simultaneously within a problem building. The challenge is to identify the cause or causes of the health complaints of those who allege that they have become ill as a result of a building they occupy and then locate the source or sources. The first step in solving the mystery is to develop a solid understanding of the mechanisms of BRIs and the offending agents associated with each mechanism. ${ }^{2}$

Building related illnesses(BRD) and Sick-building syndrome (SBS) are an increasingly a common problem in developed countries and are expected to increase in developing countries. ${ }^{3,4}$ Increasingly, physicians are being asked to evaluate patients with putative environmentally associated illnesses. These can include a variety of problems, including infectious illnesses (Legionnaire's disease), chemical exposure in the workplace, and sick building syndromes. ${ }^{5}$

\section{Terminology}

The terminology used to describe illnesses caused by building environmental factors can cause confusion. Building-associated illness refers to any illness caused by indoor environmental factors. We divide buildingassociated illness into two categories: sick building syndrome (SBS) and building-related illness (BRI). Excluded from these categories are illnesses that have a long latency period (e.g., lung cancèr caused by radon exposure). The term building-related illness applies to those adverse health effects for which we have a well-defined link between environmental agents in a specific building and the resultant health disorders. This class of illnesses frequently involves the skin and respiratory tract because of the ease with which indoor environmental contaminants come in contact with these tissues. ${ }^{2}$

SBS describes a complex of vague, predominantly subjective complaints consisting of neurobehavioral symptoms such as memory loss, headache, depression, dizziness, and respiratory complaints such as chest tightness, coughing, and shortness of breath. Burning eyes, nose, throat, and sinuses are symptoms of mucous membrane irritation that are frequently associated with "sick" building complaints. Itching and rashes may occur. However, the exact pathophysiologic mechanisms explaining how environmental factors cause "sick" building symptoms remain elusive. Studies, both in the United States and in
Europe, conducted over the past 20 years indicated that many of these buildings shared a common problem of inadequate ventilation. Yet, data to support the hypothesis that inadequate ventilation in the absence of identifiable pathogenic levels of contaminants causes human illness remain sparse. Even more importantly, it has been difficult to demonstrate, in properly designed studies, objective evidence of cause and effect between the ubiquitous chemical compounds found in all indoor environments and many of the neurobehavioral symptoms reportedly associated with SBS. However, a few well-designed studies suggest that certain functions, such as shortterm memory, mental efficiency, and visuospatial functioning, may be adversely affected by volatile organic compounds. The term building-related illnesses refers to reasonably well characterized human illnesses caused by indoor environmental factors that can be related to the clinical and laboratory findings in those building occupants with health complaints, based on validated principles of pathophysiology. ${ }^{2}$ Other definition by Seifert mentioned that the term "sick building syndrome" (SBS) has been used for several years to describe a number of mostly unspecific complaints of some occupants of airconditioned buildings. Engelhart ${ }^{6}$ classified a group of health problems related to the indoor environment-generally termed as sick building syndrome (SBS)

\section{Multi Factorial}

SBS is a multifactorial event which may include physical, chemical, biological as well as psychological factors.In many cases, the occurrence of SBS in a building is due to insufficient maintenance of the HVAC system. A broad range of pollutants is present in indoor spaces. Even something as easily recognized as environmental tobacco smoke consists of multiple pollutants that cause irritation and annoyance. The specific culprits are still unknown. Nevertheless, the broad range of pollutants trigger responses in several receptors. How effects on similar receptors can be summed remains uncertain. When agents affect the same receptor, such as the "irritant" receptor of the trigeminal nerve (common chemical sense), it is reasonable and possible to model their joint effects. On the other hand, different chemical classes may trigger that receptor differently. Where irritants have differing mechanisms of action, their interactions (antagonism and synergism) remain unpredictable. Given the broad range of agents and their influences that are present in indoor spaces, ranging from 
particulates to volatile organic compounds and ait currents, joint modeling and effect estimation is certainly difficult now and may remain impossible. At the present we do not know enough to identify all important compounds in the indoor air that cause annoyance and odor or how to sum their effects. ${ }^{7}$

Ooi et $\mathrm{al}^{8}$ found an incremental trend in prevalence of sick building syndrome among office workers in Singapore who reported high levels of physical and mental stress, and decreasing climate of co-operation. This association was confirmed after multivariate adjustment for significant personal and environmental exposure factors. Using a subsample, further modelled interaction between stress and the other covariates but none achieved statistical significance. This study confirmed stress to be a significant and independent determinant of the health complaints, and that symptoms compatible with the sick building syndrome in many cases were stress-related. Our findings underscore the importance of personal and organizational stress management to prevent ill health at the office. ${ }^{8}$

Li et al found a significant relationship between dampness and work-related sick building syndrome in the day-care-center workers. Furthermore, concentrations of fungi were lower in the day-care centers equipped with air conditioners/air cleaners than in centers that lacked such equipment. Also, Aspergillus was associated strongly with work-related sick building syndrome in the day-care-center workers. ${ }^{9}$ Engelhart et $\mathrm{al}^{6}$ present an investigation of SBS in employees of a ministry working in a naturally ventilated office building that formerly had been used by a pharmaceutical company. The highest level of complaints was found among the employees working in rooms that in the past had been used for the production or storage of various pharmaceutical products suggesting that pharmaceutical odors may be a risk factor for SBS. The authors conclude that the former use of a building for production and storage of pharmaceutical products should be considered as a possible. risk factor for complaints about indoor air quality, e.g., when advising about or planning for renovations of buildings formerly used for production, handling, or storing of chemicals. ${ }^{6}$

There has been increased concern over health effects related to potential exposure of building occupants to bioaerosols. Trout et $\mathrm{al}^{10}$ report the case of a worker with a respiratory illness related to bioaerosol exposure in a water-damaged building with extensive fungal contamination. The authors performed environmental tests to evaluate potential exposure to fungi, and we used mycotoxin-specific IgG antibody in serologic studies in the attempt to evaluate exposure to mycotoxins. Extensive fungal contamination was documented in many areas of the building. Penicillium, Aspergillus, and Stachybotrys species were the most predominant fungi found in air sampling. Our serologic test was not useful in differentiating workers who were probably occupationally exposed to mycotoxins from those who were not; however, it did yield evidence that individuals may make specific IgG antibodies to macrocyclic tricothecene mycotoxins. Further research is needed concerning health effects related to bioaerosol exposures, particularly regarding markers of exposure to specific fungi that may produce ${ }^{10}$ mycotoxins. In the absence of clinical tools specific for evaluation of mycotoxin-related illness, a systematic clinical approach for evaluating persons with suspected building-related respiratory illness is warranted. ${ }^{10}$

Engvall et $\mathrm{al}^{11}$ perform a study to analyze relationships between symptoms compatible with sick building syndrome (SBS) on one hand, and different indicators of building dampness in Swedish multifamily buildings on the other. The study was done in Stockholm, 609 multi-family buildings with 14,235 dwellings were identified, and selected by stratified random sampling with a response rate of $77 \%$. Their result showed that condensation on windows, high air humidity in the bathroom, mouldy odour, and water leakage was reported from $9.0 \%, 12.4 \%, 7.7 \%$ and $12.7 \%$ of the dwellings, respectively. In total $28.5 \%$ reported at least one sign of dampness. All indicators of dampness were related to an increase of all types of symptoms, significant even when adjusted for age, gender, population density, type of ventilation system, and ownership of the building. A combination of mouldy odour and signs of high air humidity was related to an increased occurrence of all types of symptoms $(O R=3.7-6.0)$. Similar findings were observed for a combination of mouldy odour and structural building dampness (water leakage) $(\mathrm{OR}=$ 2.9 5.2). In addition, a dose-response relationship between symptoms and number of signs of dampness was observed. In dwellings with all four dampness indicators, OR was $6.5,7.1,19.9,5.8,6.1,9.4,15.0$ for ocular, nasal, throat, dermal symptoms, cough, headache and tiredness, respectively. The authors conclusion mentioned that signs of high air humidity, as well as of structural building dampness, are common in multi-family buildings in Stockholm. 
Reports of building dampness in dwellings is related to a pronounced increase of symptoms compatible with the SBS, even when adjusted for possible confounding by age, gender, population density, and building-related risk factors. ${ }^{\text {I" }}$

Indoor air polution in the building are quietly related with various respiratory diseases particularly in asthma because of the association of mold and increased bronchial responsiveness. Recently, attention has been focused on the mold Stachybotrys in human disease. Stachybotrys was first identified more than 60 years ago following an epidemic of stomatitis, rhinitis, conjunctivitis, pancytopenia, neurologic disorders, and death in horses. Since then, Stachybotrys has been identified in several outbreaks of disease in animals. It has also attracted attention as a possible agent in idiopathic pulmonary hemorrhage in infants. Stachybotrys is a relatively uncommon fungus but has been isolated from a variety of sources, including contaminated grains, tobacco, indoor air, insulator foams, and water-damaged buildings with high humidity. This fungus is particularly important because it is one of a series of fungi that produces trichothecenes mycotoxins; these mycotoxins are biologically active and can produce a variety of physiological and pathologic changes in humans and animals, including modulation of inflammation and altered alveolar surfactant phospholipid concentrations. The presence of Stachybotrys in a building does not necessarily imply a cause-ànd-effect relationship with illness, but should alert physicians and healthcare professionals to do more vigorous environmental testing. ${ }^{5}$

Chang et al ${ }^{12}$ mentioned that not only the potential and unique infectious diseases. but also the implicating noninfectious etiologies of sick building syndrome and building-related illnesses. In addition, there are quite a role of psychological factors and mass hysteria in indoor pollution, with respect to the nature of associations between exposure and symptoms. ${ }^{12}$ Thorn ${ }^{13}$ found that long drawn conflictive processes within the building were also a factor in chronically sick building. It was revealed that the organisation for dealing with environmental problems was split, and ineffective with poor patterns of communication. It was suggested that this generated a situation of chronic stress leading to the persistence of symptoms. The results of Thom's study suggest that psychosocial factors, among them organisational structures and communication patterns, should be given close attention. $^{13}$

\section{Signs \& symptoms}

Although objective physical abnormalities of SBS are not generally found except in a few specific diseases like Legionnaires' disease, the symptoms can be uncomfortable and even disabling. It is commonly accepted to represent eye, nose, and throat irritation; headaches, lethargy, difficulty concentrating, and sometimes dizziness; nausea, chest tightness; and other symptoms. ${ }^{3,4,5}$

Table 1. SBS signs and symptoms

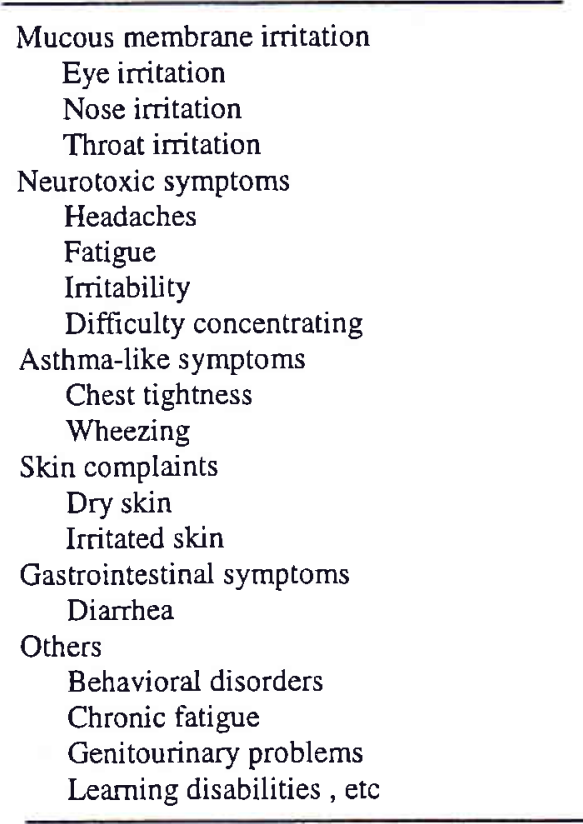

(Modified from ref $3 \& 4$ )

Although objective physiological abnormalities are not generally found and permanent sequelae are rare, the symptoms of SBS can be uncomfortable, even disabling, and whole workplaces can be rendered nonfunctional. ${ }^{4}$ It is commonly accepted to represent eye, nose, and throat irritation; headaches, lethargy, difficulty concentrating, and sometimes dizziness; nausea, chest tightness; and other symptoms. Evidence suggests that what is called the SBS is at least three separate entities, each of which has at at least one cause. ${ }^{14}$

Wyon et $\mathrm{al}^{15}$ assessed the perceived air quality and SBS symptoms while performing simulated office work. The subject-rated acceptability of the perceived air quality in the office corresponded to $22 \%$ dissatisfied when the pollution source was present, and to $15 \%$ dissatisfied when the pollution source was 
absent. In the former condition there was a significantly increased prevalence of headaches $(\mathrm{P}=$ 0.04 ) and significantly lower levels of reported effort $(\mathrm{p}=0.02)$ during the text typing and calculation tasks, both of which required a sustained level of concentration. In the text typing task, subjects worked significantly more slowly when the pollution source was present in the office $(P=0.003)$, typing $6.5 \%$ less text than when the pollution source was absent from the office Reducing the pollution load on indoor air proved to be an effective means of improving the comfort, health and productivity of building occupants. ${ }^{15}$

\section{Diagnosis}

Indoor air and the sick building syndrome (SBS) serves as a paradigm of modern occupational and environmental medicine with its inherent scientific uncertainties, expectations, and knowledge on the part of affected persons, and economic conflicts between owners, managers, tenants, and occupants. The first approach physicians generally take with patients who have a specific concern regarding potential environmentally caused disease is to obtain a careful medical and occupational history and perform a physical examination and, when applicable, laboratory tests. The first goal is to exclude other conditions that might be causing the problem. Physicians may identify an underlying condition (such as inadequate tear film production and stability or fatigue associated with hypothyroidism) associated with other diseases that may influence the pertinent symptoms. The next step is to identify the likely pathophysiologic mechanism underlying the complaint and quantify organ function. Complaints of chest tightness or wheezing require documentation of changes in airways related to work using peak expiratory flow tracings or spirometry before and after work. If no abnormality is found, no "measurable disease" is present. That is, physicians can convincingly state that even if discomfort is present, it does not represent measurable pathology. 'As always, timing in disease is important; disease may progress, and tests may need to be repeated if a patient's condition worsens. Physicians must also recognize that the appropriate test has sometimes not been applied or even identified. When discomfort is convincingly associated with particular work environments and no physiologic dysfunction is identified, the absence of "disease" makes it possible for physicians to explain both the ubiquitousness of discomfort and irritation and the idea that discomfort does not usually represent true disease that progresses or leads to disability. Such discussions are designed to prevent destructive illness behavior. $^{\text {? }}$

In the absence of physiologic dysfunction or anticipated impairment, the question is always raised as to whether some discomfort may have to be tolerated in the workplace in the same fashion as at home or on the street. One aspect of the discussion is to refocus the problem to discomfort and economic trade-offs for employers. It is often much easier to persuade employers that general irritation may lead to discomfort and decreased productivity than to deal with adversarial workers' compensation procedures. Such an approach will work only if there is general agreement on goals of solving problems. If patients do not have measurable or identifiable disease, they may have complaints consistent with the SBS. As the description here makes clear, the physiologic basis of the SBS is under active investigation. Even as the arguments are being made that the syndrome is primarily a matter of discomfort, efforts to explain that discomfort suggest that there are identifiable physiologic responses to the "sick building" environment. To date there is no evidence suggesting that these responses lead to long-term impairment or established disease. Nevertheless, several investigations cited under the appropriate organ system suggest that conditions in general may be associated with at least physiologic if not pathologic responses. ${ }^{7}$

Table 2. Investigation methods

Eye
Tear film break-up time
Fat layer determination
Conjunctival photography
Lissamine green staining (punctate conjunctivitis)
Nose
Acoustic rhinometry
Anterior and posterior rhinomanometry
Nasal lavage
Stereoscopic microscopic examination
Chest
Peak flow meters
Spitometry
Central nervous system
Neuropsychologic testing
Evoked potentials
Vestibular testing with solvent provocation

(Cited from ref 7) 
Chest tightness and asthma-like symptoms are common. Some persons have documentable variability in their airways caliber related to work; asthma caused by or exacerbated by a particular environment is traditionally not 'considered part of the SBS. One report describes the new development of asthma and exacerbations in the workplace in a group of office workers. Other workers in the building described excess coughing, wheezing, and mucous membrane irritation. Outbreaks of hypersensitivity pneumonitis have demonstrated a similar association. This suggests that at least some office workers may have unrecognized asthma or pneumonitis. There may be another group of persons who have subjective chest tightness, wheeze, or cough in whom there is no physiologic abnormality. This occurrence may be associated with -1,3-glucan exposure. Use of peak flow meters and spirometry before and after exposure is essential in efforts to differentiate building-related asthma from SBS and to clarify whether this symptom complex is distinct from reactive airways disease.

In summary, individual complaints may be characterized and attempts at confirmation or quantification undertaken. The absence of physiologic abnormalities may allow physicians to move the level of patient discourse to discomfort rather than disease. On the other hand, if individual patients have convincing symptoms alternative approaches to documentation must be undertaken. These include traditional challenge tests or n-of-one clinical trials.

Patients are usually a member of some group defined through common exposures. They may perceive themselves as the most sensitive persons or simply be the only ones willing to voice complaints. It is rare for an office to generate complaints in only a single patient. If diagnostic tests in individual patients alone are inconclusive but strong suspicion continues to exist, physicians may then choose to examine the group members informally, dùring a walk-through, or formally. Group measurements should be undertaken thoughtfully, with a clearly defined goal. This goal may be to obtain more information on the spectrum or prevalence of complaints, to compare symptom frequencies with-some external control groups (other buildings), or to address disease. ${ }^{7}$

On-site assessment of buildings is extremely useful. Thorn $^{13}$ investigate the merits of case studies as complementary methodological approaches in the study of the sick building syndrome in a Swedish office building with longstanding health problems, and its inhabitants. By their capacity to identify internal processes within building contexts, case study methodology can contribute to a better understanding and management of sick building syndrome. ${ }^{13}$ Hodgson $^{16}$ mentioned that in the majority of cases, engineering problems and pollutant sources can be identified that contribute to the generation of complaints. Although psychosocial factors are likely to exacerbate underlying complaints, they should not distract from identifying solutions. ${ }^{16}$

\section{Control}

In assessment of patients with SBS complaints, specific building-related illnesses suggested by history or physical examination should be ruled out. On-site assessment of buildings is extremely useful. Treatment involves both the patient and the building. Whenever possible, changes such as ventilation improvements and reduction of sources of environmental contamination should be initiated even if specific aetiological agents have not been identified. ${ }^{4} \mathrm{Ooi}^{8}$ mentioned that a biopsychosocial approach is needed to the problem involving symptomatic treatment, environmental control, good ergonomic design, and stress management in SBS. Redlich stressed that treatment should involves both the patient and the building. Whenever possible, changes such as ventilation improvements and reduction of sources of environmental contamination should be initiated even if specific aetiological agents have not been identified. ${ }^{4}$

Prevention through a proactive air quality monitoring program is far more desirable than dealing with an actual sick building. Regardless, there are effective, rational approaches for diagnosing sick buildings. In the upcoming years, it is inevitable that extensive air monitoring will be required in all commercial buildings. $^{\text {I7 }}$

The sick building syndrome (SBS) has been the subject of serious scientific inquiry only in the past 10 years. ${ }^{15}$ New directions for indoor environment research are in the following 4 themes: (i) the current change in office work pattern, workplace design, and increasing demands from the work force, (ii) the large individual variation in requirements for optimal conditions pointing at the key factors of individual response and individual control options hased on trade-off experiments, (iii) psychosocial factors as determinants of symptoms, comfort, and productivity, and (iv) transient, nonspecific symptoms in the indoor 
environment, the identification of causes, and longterm consequences. ${ }^{18}$

The sick building syndrome has been widely discussed from epidemiological perspectives. Although there is considerable difference in opinion regarding the concrete and objective evidence to support a distinct sick building syndrome and/or building-related illness, much data indicates that numerous variables within buildings can potentially influence human health. Different building construction types of old versus new buildings to highlight changes in modern construction may have led to a putative increase in work-related symptomatology. ${ }^{12}$

Some of the emerging events that are assuming increasing relevance as work-related respiratory diseases (indoor air pollution and sick building syndrome, respiratory toxicity of formaldehyde, pollutant-induced asthma, dental technician lung diseases, lung cancer from diesel exhaust, environmental silicosis). The industrial hygienist's role in recognition, evaluation, and control of health hazards is stressed as an essential contribution to both prevention and diagnosis of occupational lung disease. ${ }^{19}$ Workerrelated complaints of sick building and/or buildingrelated illnesses are being recognized increasingly. Clinicians need to become more familiar with these syndromes which include asthma, humidifier fever, hypersensitivity pneumonitis and allergic rhinitis. ${ }^{20}$ In addition, various infectious diseases such as legionellosis, Q fever and viral respiratory conditions may be building exposure linked. Finally, toxin exposures to indoor air chemicals ranging from volatiles, copy paper, glue, and pesticides may be linked to health sequelae. Thus, these patients should have serious considerations, particularly where cluster illnesses with documented respiratory disorders and skin rashes are identified. Appropriate measures for diagnosis, treatment, documentation and advocacy for employee relocation pending corrective actions should follow. ${ }^{20}$

The collision of escalating technological sophistication and surging environmental awareness has caused the reexamination of many societal paradigms. Horror stories about lethal chemical exposures involving isolated cases of ignorance, carelessness or greed have caused the public to demand constant vigilance to prevent exposure to potentially hazardous substances. Accordingly, much time and resource has been expanded by the U.S. government and citizens to abate and prevent air and water pollution. While these efforts have met with measurable success, there is increasing public concern about a new generation of pollution-related human illness in office, home and transportation environments. New instances of Sick Building Syndrome or Building Related Ilness are reported daily by the popular press. Human health effects such as cancer, infectious disease, allergy and irritation have been ascribed to indoor air pollution. The clinical aspects of indoor air pollution are often discounted by consulting engineers and industrial hygienists involved in indoor air quality. Physicians and clinically-trained scientists have received a "Macedonian call" to sift clinical relevance from the emotional aspects of indoor air quality problems. Point sources of pollutants, associated human health effects, and problem solving approaches associated with indoor air pollution are described. Regulatory and litigational aspects of indoor air pollution are also important part that should be discussed. ${ }^{21}$

Indoor air and the sick building syndrome (SBS) serves as a paradigm of modern occupational and environmental medicine with its inherent scientific uncertainties, expectations, and knowledge on the part of affected persons, and economic conflicts between owners, managers, tenants, and occupants. ${ }^{7}$ As we develop a better understanding of the adverse effects of the indoor environment on health, the pathophysiologic mechanisms contributing illnesses caused by indoor environmental factors will become more clearly defined. ${ }^{2}$ The term building-related illness applies to those adverse health effects for which we have a well-defined link between environmental agents in a specific building and the resultant health disorders. This class of illnesses frequently involves the skin and respiratory tract because of the ease with which indoor environmental contaminants come in contact with these tissues. A'gents that cause buildingrelated illnesses generally induce illness by one of four mechanisms: (1) immunologic, (2) infectious, (3) toxic, or (4) irritant. Some agents may work through more than one mechanism.

\section{REFERENCES}

1. Brownson K. Hospital air is sick. Hosp Mater Manage Q $2000 ; 22(2): 1-8$

2. Seltzer JM , Building-related illnesses. J Allergy Clin Immunol 1994;94:351 - 62

3. Sabir M, Shashikiran U, Kochar SK. Building related illnesses and indoor air pollution. $J$ Assoc Physicians India $1999 ; 47(4): 426-30$ 
4. Redlich CA, Sparer J, Cullen MR. Sick-building syndrome. Lancet $1997 ; 349(9057)$ : 1013-6

5. Mahmoudi M, Gershwin ME. Sick building syndrome. III. Stachybotrys chartarum. J Asthma 2000; 37(2):191-8

6. Engelhart S, Burghardt H, Neumann R, Ewers U, Exner $\mathrm{M}$, Kramer MH. Sick building syndrome in an office building formerly used by a pharmaceutical company: a case study. Indoor Air 1999; 9(2):139-43

7. Hodgson, M, Storey, E, , Conn S. Patients and the sick building syndrome. Multiple contaminants problem. J Allergy Clin Immun 1994; 94 (2):374-6

8. Ooi PL, Goh KT. Sick building syndrome: an emerging stress-related disorder? Int J Epidemiol 1997; 26(6):12439

9. $\mathrm{Li} \mathrm{CS}$, Hsu CW, Tai ML. Indoor pollution and sick building syndrome symptoms among workers in day-care centers. Arch Environ Health 1997; 52(3):200-7

10. Trout D, Bernstein J, Martinez K, Biagini R, Wallingford $\mathrm{K}$. Bioaerosol lung damage in a worker with repeated exposure to fungi in a water-damaged building. Environ Health Perspect 2001; 109(6):641-4

11. Engvall K, Norrby C, Norback D. Sick building syndrome in relation to building dampness in multi-family residential buildings in Stockholm. Int Arch Occup Environ Health 2001; 74(4):270-8

12. Chang CC, Ruhl RA, Halpern GM, Gershwin ME. Building components contributors of the sick building syndrome. J Asthma 1994;31(2):127-37.
13. Thom A. Emergence and preservation of a chronically sick building. J Epidemiol Community Health 2000; 54(7):552-6

14. Apter A, Bracker A, Hodgson M, Sidman J, Leung WY. Epidemiology of the sick building syndrome. J Allergy Clin Immunol 1994; 94(2 Pt 2):277-88.

15. Wyon DP, Baik YK, Clausen G, Fanger PO. Perceived air quality, sick building syndrome (SBS) symptoms and productivity in an office with two different pollution loads. Indoor Air 1999; 9(3):165-79

16. Hodgson $M$. The sick-building syndrome. Occup Med 1995; 10(1):167-75

17. Montz WE Jr. Indoor air quality in hospitals. Med Waste Anal 1993; 2(2): 1, 3-7

18. Schneider T, Skov $P$, Valbjom $O$. Challenges for indoor environment research in the new office. Scand $J$ Work Environ Health 1999; 25(6):574-9

19. Franco G. New trends in occupational and environmental diseases: the role of the occupational hygienist in recognizing lung diseases. Monaldi Arch Chest Dis 1994; 49(3):23942

20. Sherin KM. Building-related illnesses and sick building syndrome. J Fla Med Assoc 1993; 80(7):472-4

21. Brooks BO, Utter GM, DeBroy JA, Schimke RD. Indoor air pollution: an edifice complex. J Toxicol Clin Toxicol $1991 ; 29(3): 315-74$ 